\title{
Cointegration Analysis of Rural Wheat Markets in Northem Bangladesh
}

\author{
Mohammad Ismail Hossain*, Eleni Papadopoulou, ${ }^{* *}$ and \\ Mst. Esmat Ara Begum***
}

\begin{abstract}
This paper examines the cointegration of wheat market prices in Northern Bangladesh. Results are based on weekly wholesale price data on wheat collected from the Department of Agricultural Marketing (DAM) in eight markets in the Rangpur division of Northern Bangladesh. The data has 208 observations for wheat in each of the eight markets ranging over a period of January 2006 to December 2009. Johansen's cointegration test reveals that most of the wholesale markets of wheat in the Rangpur division are co-integrated which indicates that price signals and information are transmitted smoothly across the markets. The discovery of the market integration appears to be quite significant for the success of price policy and market liberalization programs which are being undertaken in Bangladesh.
\end{abstract}

Key words: Price cointegration, wholesale wheat markets and error correction model.

Submission Date: 8/6/2011 Revision Date: 10/1/2011 Acceptance Date: 10/31/2011

* Corresponding Author, Ph.D candidate, Department of Agricultural Economics, School of Agriculture, Aristotle University of Thessaloniki, Thessaloniki, Greece, Phone: 00302310 857039, Mobile: 0030 6949027192, E-mail: mhossain@agro.auth.gr

** Assistant Professor, Department of Agricultural Economics School of Agriculture, Aristotle University of Thessaloniki, Tel., Fax., +302310998816 E-mail:epapa@agro.auth.gr

*** Ph.D candidate, Department of Agricultural Economics, School of Agriculture, Aristotle University of Thessaloniki, Thessaloniki, Greece, Phone: 00302310 857039,E-mail: begum@agro.auth.gr 


\section{Introduction}

The market integration concept has retained and increased in importance over recent years, particularly in developing countries where it has potential applications for policy questions regarding government intervention in markets (Alexander and Wyeth, 1994). Unless agricultural product markets are spatially integrated, producers and consumers will not realize the gains from trade liberalization. If markets are not integrated, the correct price signals will not be transmitted through the marketing channels, the farmers will not be able to specialize according to long-term comparative advantage and gains from trade will not be realized.

In most cases, agricultural markets in developing countries are less integrated due to the lack of well developed infrastructure, market institutions and market information which facilitates the easy flow of goods and services between markets (Minten, 1999). The majority of the rural agricultural markets in Bangladesh have this feature. Under such circumstances, rural markets may not be able to make quick adjustments when price shocks occur in neighboring markets (Hossain and Verbake, 2010).

Most of the studies related to grain market integration in Bangladesh have mainly focused on how the regional market prices are cointegrated to the central grain market in Dhaka (Goletti et al., 1995; Das et al., 1997; and Hossain and Verbeke, 2008). Such studies are relevant since the Dhaka grain market is the core element for determining grain prices. However, fewer attempts have been made to try to examine how local markets are cointegrated and how they adjust to price shocks in their neighboring markets or to their immediate regional markets. With this understanding, this paper tries to analyze the extent of wheat market integration in northern Bangladesh when using wholesale prices.

In recent years several studies relating to market integration have been done with the help of different statistical tools. The usual definition in literature states that integrate markets are those where prices are determined interdependently. This has generally been assumed to mean that price changes in one market will be fully transmitted into other markets (Behura and Pradhan, 1998). In making inferences about market efficiency from data on prices, the concept of integration has been central (Palaskas and Harriss-White, 1993). Spatial market integration refers to a situation in which prices of a commodity in spatially separated markets move together while price signals and information are transmitted smoothly across the markets (Ghosh, 2000). In the sixties and the seventies, the methodological work on the measurement of price efficiency in the agricultural commodity markets focused on pair-wise comparisons of price series data, i.e., the zero order correlation coefficient. Price series correlation is regarded as a convenient indicator of market integration (Gilbert, 1969; Illori, 1968; Cummings, 1967 Lele, 1967; 1971’; Jones, 
1972; Gupta, 1973; Thakur, 1974). This approach has been strongly criticized despite its simplicity in the literature on market performance in rural areas (Blyn, 1973; Harriss, 1979; Heytens, 1986; Ravallion, 1983; 1986). The studies based on bivariate correlation, have also been criticized because of their methodological shortcomings. The most serious criticism of bivariate correlation seems to have occurred due to its failure to recognize the possibility of spurious integration in the process of a common exogenous trend (e.g., general inflation), common periodicity (e.g., agricultural seasonality) or auto correlated and heteroscedastic residuals in the regression with non-stationarity price data (Barrett, 1996) and Palaskas and Harriss-White, 1993, hereafter PHW).

In the year 1980, several attempts were made to improve upon earlier methods. The most significant contribution to the market integration method came from Ravallion (1986). In order to test the alternative hypotheses of market integration, he proposed a dynamic model of spatial price differentials. Although this method mitigates the major methodological limitations of the bivariate correlation method, it still contains serious problems which result in inefficient estimators, which are used for testing the alternative hypotheses of market integration and segmentation (PHW, 1993).

Recent advances in time-series analysis mainly related to cointegration and error correction method have led to an explosion in literature regarding testing for food market integration in many developing countries including Bangladesh (Asche et al., 1999; Goletti et al., 1995; Dercon, 1995; Alexander and Wyeth, 1994; Dahlgram and Blank, 1992; Goodwin and Schroeder, 1990; Faminow and Bension, 1990; Palaskas and Harriss-White, 1993; Baharumshah and Habibullah, 1994; Behura and Pradhan, 1998; Sexton, Kling and Carman, 1991; and Ghosh, 2000).

PHW's study, however, involved methodological defects inherent in the Engle and Granger (1987) method of cointegration. The most undesirable feature of the Engle and Granger (1987) procedure was that the test results may be very sensitive to the choice of the variable selected for normalization (i.e. the left-hand side in the regression). This problem is obviously compounded when there are more than two variables. Moreover, the method does not provide any procedure for testing multiple cointegrating vectors when there are three or more variables. Naturally, when conducting the test for market integration properly by the Engle-Granger cointegration method, it is necessary to identify the central (exogenous) and peripheral (endogenous) markets.

A much better way to resolve this problem is to use the multivariate cointegration method developed by Johansen (1988) and Johansen and Juselius (1990). This method treats all the variables as explicitly endogenous and takes care of the endogenity problem by providing an estimation procedure which does not require arbitrary choice of a variable for normalization. It also allows testing for multiple cointegrating vectors. 
Much of the relevant literature in Bangladesh concerns the market integration of rice. Thus far, research concerning the market integration of wheat has been inadequately dealt with, although, wheat is the second most important grain and dish for the Bangladeshi people. However, no work has been done in the way of empirically evaluating wheat market integration in northern Bangladesh with the help of the recently developed cointegration test by Johansen (1988) and Johansen and Juselius (1990).

Against this backdrop, the objective of the present study is to evaluate empirically spatial integration of the wheat markets in the Rangpur division of northern Bangladesh. In order to do this, it is necessary to compare the market prices of wheat in one market with the prices of comparable varieties among the other markets in the division. At first, we hypothesized that wheat markets are spatially integrated when wholesale prices are taken into consideration. The Maximum Likelihood (ML) method of the coitegration test developed by Johansen and Jeselius (1990) has been used to check for market integration.

\section{Methodology}

For analyzing spatial integration, data pertaining to the weekly wholesale prices of wheat flour (white) were collected from the Department of Agricultural Marketing, the Government of the People's Republic of Bangladesh for the period of January 2006 to December 2009. Data on prices pertaining to the Friday of each week for twelve months was also collected. The prices were reported in tk/quintal. The selected districts under the Rangpur division are Rangpur Sadar, Dinajpur, Kurigram, Gaibandha, Lalmonirhat, Nilphamari, Thakurgoan and Panchagorh.

A three stage procedure was followed to test for a price cointegration among the markets and estimate the adjustment parameters were used for the Vector Error Correction Model (VECM). In the first step, using the Augmented Dickey-Fuller (ADF) (Dickey and Fuller, 1981) and the Phillips-Perron (PP) (Perron, 1988) unit root tests, the series of commodity prices in different markets are tested for stationarity. The ADF test is a parametric test (predetermined parameters) and it has little power, whereas the PP test statistic is based on a non-parametric modification of the Dickey-Fuller tests. Hence, we give more significance to the PP than to the ADF test. Once the stationarity is confirmed, the number of maximum lags to be included in the cointegration test or the cointegrating VECM estimation is identified. Though there are a number of criteria which can be used in selecting the lag orders, the Akaike Information Criterion (AIC) is the most commonly used.

Using the selected lag orders, the following Johansen's $(1988,1991)$ method is applied 
Using the selected lag orders, the following Johansen's $(1988,1991)$ method is applied to test the existence of the cointegration among a series of market prices.

$$
X_{t}=A_{0}+A_{1} X_{t-1}+--------+A_{p} X_{t-p}+v_{t} \quad ; \mathrm{t}=1,2,----\mathrm{T},
$$

where $\mathrm{p}=$ lag length; $\mathrm{Xt}=\mathrm{an}(\mathrm{n} \times 1)$ vector of endorgenous variables; A's are matrices of unknown parameter; ot is an independently distributed(iid) $n$ dimensional vector with zero mean and variance matrix et.

Following Johansen (1988), Johansen and Juselius (1990) a general system of regression equations is stipulated:

$$
\Delta X_{t}=\tau_{0}+\tau_{1} \Delta X_{t-1}+---------+\tau_{p-1} \Delta X_{t-(p-1)}+\Pi X_{t-p}+v_{t}
$$

or

$$
\Delta{\mathrm{Xt}=\mathrm{t}_{0}+}_{j=1}^{p-1} \tau_{j} \Delta \mathrm{X}_{\mathrm{t}-1}+\Pi \mathrm{X}_{\mathrm{t}-\mathrm{p}}+v_{\mathrm{t}}
$$

Where $\mathrm{t}_{0}=\mathrm{A}_{0}$;

$$
\begin{aligned}
& \tau_{j}=-\left(I-\sum_{j=1}^{p-1} A_{j}\right) ; \mathrm{j}=1,2----, \mathrm{p}-1 \\
& \Pi=-\left(I-\sum_{i=1}^{p} A_{i}\right)
\end{aligned}
$$

and $\Delta X_{t-j}$ is a $(n \times 1)$ vector of $X_{t-j}$ in the first differences, and $\Pi$ and $t_{j}(j=1$, $2,----, \mathrm{k})$ are $n$ by $n$ matrices of parameters and $V_{t}$ is an n-vector of residuals which are assumed to be normally distributed with a mean of $O$ and have a contemporaneous covariance matrix $\epsilon_{t}$. The long run information in $X_{t}$ is summarized by the long run impact matrix, $\Pi$. The $\Pi$ is the ranking of the matrix of the VECM which determines the number of independent co-integrating vectors. If the matrix $\Pi$ has a rank, $r$, greater than zero, then a co-integration is present. If on the other hand the rank of $\Pi$ is zero, then the variables are segmented and the model translates into a standard VAR model in differences.

Johansen and Juselius (1990) proposed two likelihood ratio test statistics to base on different assumptions about the alternative hypothesis. These are the trace statistic tests, $\lambda_{\text {Trace }}$ and the maximum eigenvalue statistic test, $\lambda_{\max }$ and are specified as follows: 


$$
\begin{aligned}
& \lambda_{\text {Trace }}(r)=-T \sum_{i=r+1}^{n} \ln \left(1-\lambda_{i}\right) \\
& \lambda_{\max }(r, r+1)=-T \ln \left(1-\left(\lambda_{-r+1}\right)\right.
\end{aligned}
$$

Equation (3) tests the null hypothesis that there are $r$ or less co-integrating vectors, i.e, $r \leq 1$, while equation (4) tests the null hypothesis that there are exactly $r$ integrating vectors, i.e., $r=1$. The test statistics are then compared to the critical values. If the calculated test statistics are greater than the critical values then the null hypothesis is rejected in each case.

Just like with the bivariate approach, the VECM is a multivariate system which conveys information on rates of adjustments and feedback effects. The $P$ matrix can be decomposed into the product of $\alpha$ and $\beta$ where $\Pi=\alpha \beta$. The short run dynamics among the variables can be evaluated by examining the significance of and the signs on the estimated lagged coefficients. The dynamic of the system can be inferred from the parameter $\alpha$ which is interpreted as the matrix of the speed adjustment coefficients. If the value of $\alpha$ is low then the system is said to adjust slowly to the deviations from the long run equilibrium. Higher values of $\alpha$ suggest a high response of the system to these deviations. If on the other hand, the value of $\alpha$ is zero, then the system is not responding to the disequilibrium error. This implies that the variables may be weakly exogenous (Chang and Griffith, 1998). The parameter $\alpha$ represents the co-integration relationships in which the disequilibrium error is stationary (Johansen and Juselius, 1990). 


\section{Results and discussion}

The original data for eight selected districts of Rangpur division markets are shown in Figure 1 while the logarithm of the districts market price series and their first difference series are presented in Figures 2 and 3. It is evident in the figures that there are some spatial variations between the districts market prices as well as some seasonal variations.

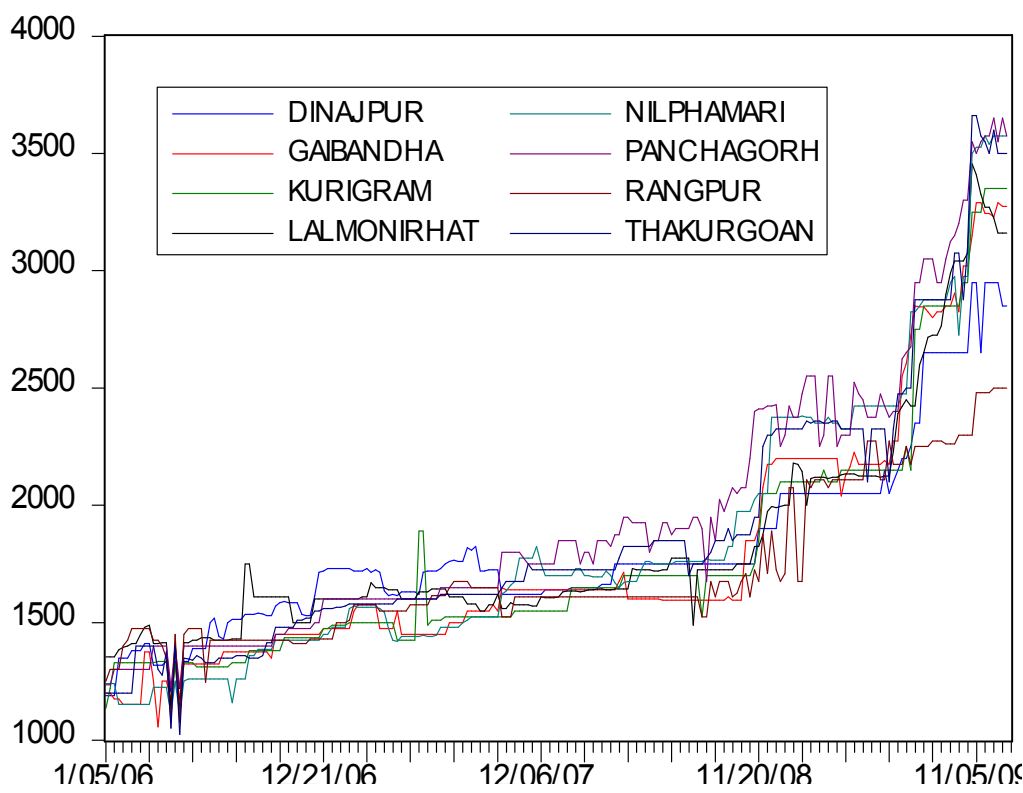

Figure 1.

Nominal wholesale wheat prices of different districts in Rangpur division (from 05/01/2006to31/12/2009) 

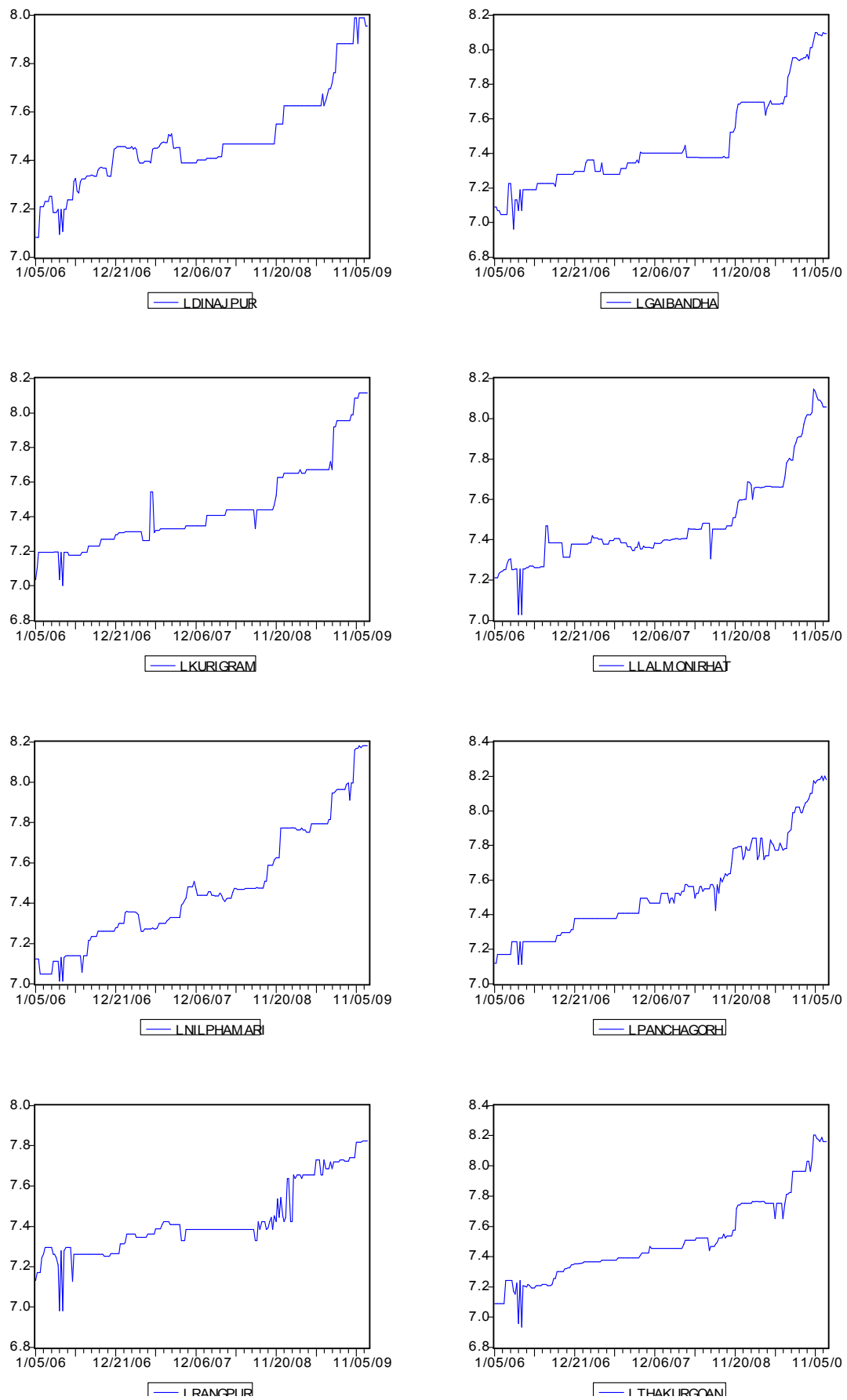

Figure 2.

Weekly log wholesale districts wheat prices in levels. 

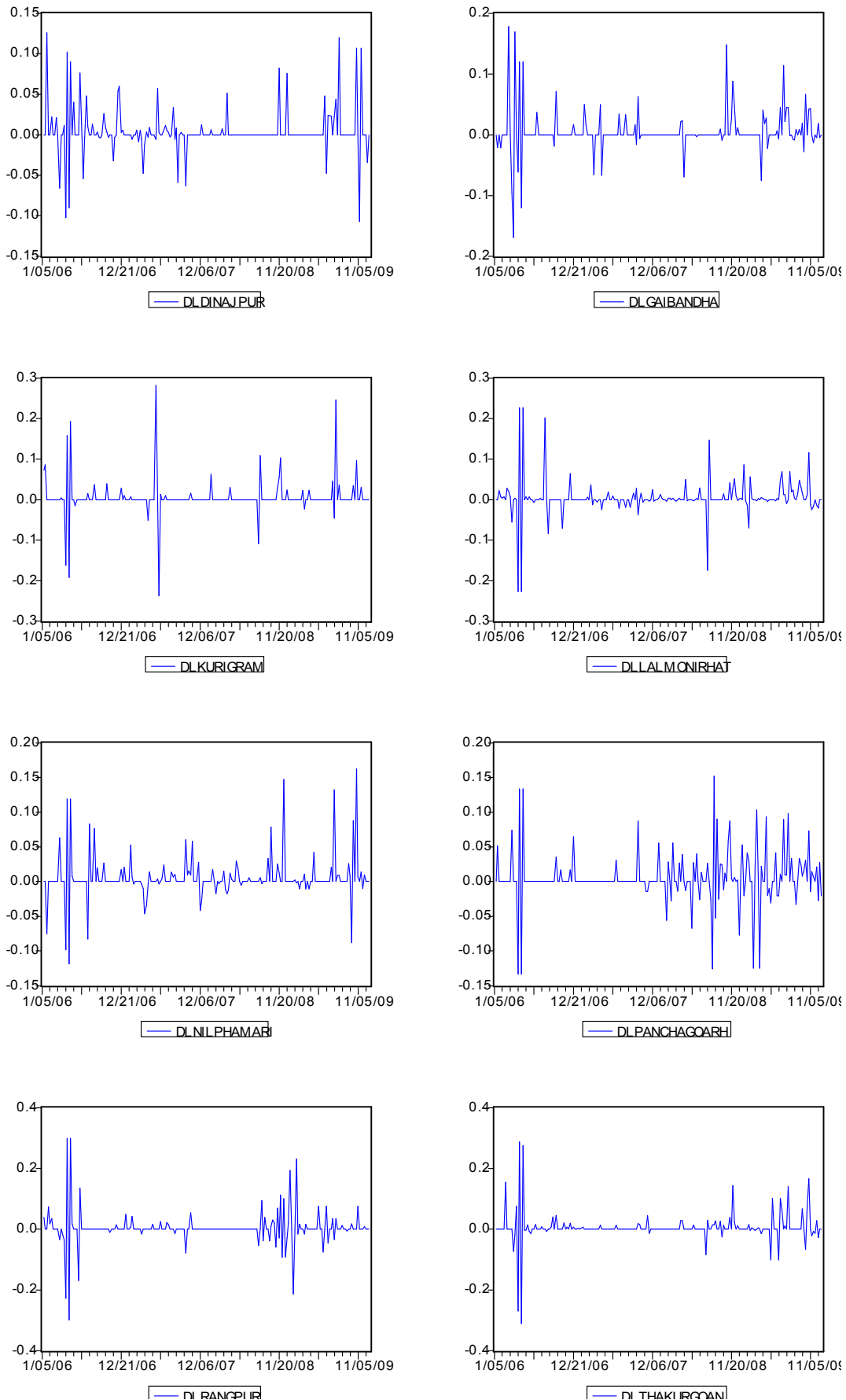

Figure 3.

Weekly log wholesale districts wheat prices in first difference 


\subsection{Stationarity test}

For testing stationarity, unit root tests have been performed in levels and the first difference of these series for all the selected markets of the Rangpur division. Testing a null hypothesis of non-stationarity against an alternative hypothesis of stationarity, the results of the Augmented Dickey-Fuller and Phillips-Perron tests statistic at levels and the first difference are shown in Table 1. The null hypothesis of non-stationarity cannot be rejected even at a $10 \%$ level for any of the price series at the level of selected markets of the Rangpur division. The Null hypothesis is rejected for all the series using the first differences. These results ensured that all the series are non-stationary at that level and stationary at the first difference. So, we can conclude from Table 1 that the wholesale prices for the selected wheat markets in the Rangpur division are integrated in the order 1, i.e., I (1).

\section{Table 1.}

Unit root test for wholesale prices of wheat in different markets of Rangpur division

\begin{tabular}{|c|c|c|c|c|c|c|c|c|}
\hline \multirow{2}{*}{ Market place } & \multicolumn{4}{|c|}{ At levels } & \multicolumn{3}{c|}{ At first differences } \\
\cline { 2 - 9 } & \multicolumn{2}{|c|}{ ADF } & \multicolumn{2}{c|}{ PP } & \multicolumn{2}{c|}{ DDF } & \multicolumn{2}{c|}{ PP } \\
\cline { 2 - 9 } & $\delta$ & $\mathrm{t}$-value & $\delta$ & $\mathrm{t}$-value & $\delta$ & $\mathrm{t}$-value & $\delta$ & $\mathrm{t}$-value \\
\hline Dinajpur & -0.011 & -0.462 & -0.026 & -1.314 & -1.182 & -5.841 & -1.231 & -18.022 \\
\hline Thakurgoan & -0.0003 & -0.009 & -0.035 & -1.519 & -1.274 & -5.98 & -1.287 & -19.147 \\
\hline Panchagorh & 0.005 & 0.238 & -0.027 & -1.277 & -1.492 & -7.046 & -1.246 & -18.232 \\
\hline Gaibandha & -0.005 & -0.293 & -0.006 & -0.393 & -0.94 & -5.583 & -1.117 & -16.017 \\
\hline Rangpur & -0.032 & -0.841 & -0.146 & -3.045 & -2.624 & -9.527 & -1.386 & -21.439 \\
\hline Kurigram & 0.002 & 0.077 & -0.018 & -0.912 & -1.484 & -7.512 & -1.211 & -17.709 \\
\hline Nilphamari & 0.006 & 0.324 & -0.01 & -0.584 & -1.136 & -6.518 & -1.187 & -17.216 \\
\hline Lalmonirhat & 0.0003 & 0.019 & -0.019 & -1.062 & -1.447 & -6.831 & -1.291 & -19.229 \\
\hline
\end{tabular}

Note: The null hypothesis in the ADF and PP tests is that the two price series under investigation I(1). In both cases the null is rejected when the calculated test statistic is less than the critical value with $-4.006,-3.433$ and -3.140 at $1 \%, 5 \%$ and $10 \%$ levels of significance respectively for 202 observations after adjusting endpoints.

Source: Weekly wheat price series from $05 / 01 / 2006$ to 31/12/2009 collected from DAM. 


\subsection{Co-integration results}

For the multivariable model, co-integration is tested using the Johansen's maximum likelihood procedure by using the two test statistics that the trace and eigenvalue specified in the equations (3) and (4). The maximum lag was 2 and was determined based on the Akaike Information Criteria (AIC) and the Schwartz Criteria (SC). Table 2 shows the cointegration results for the eight wholesale markets of the Rangpur division. The results indicate that the ranking of $\mathrm{P}$ for the maximal eigenvalue statistics is four while the ranking of $\mathrm{P}$ for the trace statistics is four. In our estimation, we found four cointegrating vectors and four common 1) trends. These results indicate that the eight price series are integrated and have long run relationships between them. On the other hand, the results of ltrace indicate that the ranking of $\mathrm{P}$ can reach five (at a 95\% level of significance) which means that there are at least five co-integrating equations in our estimation. If we select $r=6$ then the ltrace value is smaller than the critical value. The results from the trace statistics indicate that there are five co-integrating vectors and three common trends which suggest that wheat markets with in the Rangpur division are stationary in five directions and non-stationary in three directions. This indicates that the wheat markets in the Rangpur division during the study period were highly linked together and therefore the long run equilibrium is stable.

\section{Table 2.}

Results of co-integration

\begin{tabular}{|c|c|c|c|}
\hline Null hypothesis & $\begin{array}{c}\text { Maximum eigenvalue } \\
\left(\lambda_{\mathrm{max}}\right)\end{array}$ & Trace statistic $\left(\lambda_{\text {Trace }}\right)$ & $95 \%$ critical value \\
\hline $\mathrm{r}=0$ & 0.310 & $295.59^{* *}$ & 182.82 \\
\hline $\mathrm{r}=1$ & 0.253 & $219.54^{* *}$ & 146.76 \\
\hline $\mathrm{r}=2$ & 0.2253 & $159.86^{* *}$ & 114.9 \\
\hline $\mathrm{r}=3$ & 0.1865 & $107.52^{* *}$ & 87.31 \\
\hline $\mathrm{r}=4$ & 0.135 & $65.21948^{*}$ & 62.99 \\
\hline $\mathrm{r}=5$ & 0.0773 & 35.48 & 42.44 \\
\hline $\mathrm{r}=6$ & 0.0632 & 18.98 & 25.32 \\
\hline $\mathrm{r}=7$ & 0.027 & 5.61 & 12.25 \\
\hline
\end{tabular}

Note: $* * *)$ denotes rejection of the hypothesis at $5 \%(1 \%)$ significance level.

If $\lambda_{\text {Trace }}$ value exceeds the critical value, it is possible to reject the null hypothesis.

Source: Weekly wheat price series from $05 / 01 / 2006$ to 31/12/2009 collected from DAM.

1) The number of common trends is calculating by subtracting the number of conintegration vectors from the dimension of the matrix which in the case equal to eight (Ismet et al. 1998) 


\subsection{Weak exogeneity (Granger causality) test}

The results for the causality tests are inferred from the F-statistics and are presented in Table 3. The results indicate that the strength of the causality from the regional market $\mathrm{R}$ to the regional market $\mathrm{P}$ and vice-verse. A Granger causality test to establish the appropriate direction of the flow of the price information is implied if the null that there is no causality from $\mathrm{R}$ to $\mathrm{P}$, or vice versa, and is therefore rejected.

The results suggest that Dinajpur "Granger causes" price changes in Rangpur at a 1 percent level of significance. Price changes in Dinajpur are, however, Granger caused by those in Panchagorh, Gaibandha, Rangpur, Kurigram and Lalmonirhat at a 1 percent level and Thakurgoan and Lalmonirhat at a 5 percent level of significance. This indicates a two-way causation of prices between Dinajpur and Rangpur. The result for Rangpur is as expected, as it is a major surplus region for wheat. No causality was found from Dinajpur to Thakurgoan, Panchagorh, Gaibandha, Kurigram, Lalmonirhat and Nilphamari. This implies that there was a unidirectional causation originating from Dinajpur to these districts markets. In this respect Dinajpur leads the price formation process only to Rangpur, but there is bidirectional causality between these two markets.

Thakurgoan Granger causes price changes in Rangpur, Kurigram and Nilphamari at a 1 percent level and at a 5 percent level in Dinajpur and in Panchagorh at a 10 percent level of significance. However, price changes in Thakurgoan Granger are caused by all markets except Dinajpur. This implies that there is bidirectional causation between Thakurgoan and Dinajpur, Thakurgoan and Panchagorh, Thakurgoan and Rangpur, Thakurgoan and Kurigram and Thakurgoan and Nilphamari. No causality was found between Thakurgoan to Gaibandha and Thakurgoan to Lalmonirhat.

Panchagorh leads the price changes in all markets and the price of Panchagorh changes by Thakurgoan, Lalmonirhat and Gaibandha. This is due to the fact that Panchagorh is an importing region and it is also connected to India by a road. When the importing price is low, there is pressure to reduce the domestic price and vice verse. Panchagorh is also a producing region for wheat. So, it leads to price changes in the rest of the markets.

Gaibandha "Granger" causes price changes in all of the markets, and the price of Gaibandha is changed only by Panchagorh. It is expected that Gaibandha has an advantage because of its location. It is also a producing region and a distribution region of wheat to other parts of Bangladesh as wheat is distributed to the Dhaka central market and other markets through Gaibandha. Bidirectional price changes have occurred between Gaibandha and Panchagorh due to importing prices as import prices lead to changes in the domestic 
price of wheat.

The price in Rangpur changes all markets prices and Rangpur leads the price changes to Dinajpur, Thakurgoan and Kurigram. No causality was found in Rangpur to Panchagorh, Gaibandha, Nilphamari and Lalmonirhat.

The overall conclusion is that Panchagorh and Gaibandha lead the price changes in other markets of the Rangpur division. The bivariate model reveals that price changes in the Rangpur division appear to be organized through these two markets.

\section{Table 3.}

Granger causality test results

\begin{tabular}{|c|c|c|c|c|c|c|c|c|}
\hline \multirow{2}{*}{$\begin{array}{c}\text { From } \\
\text { market } \mathrm{R}\end{array}$} & \multicolumn{7}{|c|}{ To market $\mathrm{P}$} \\
\cline { 2 - 9 } & Dinajpur & Thakurgoan & Panchagorh & Gaibandha & Rangpur & Kurigram & Nilphamari & Lalmonirhat \\
\hline Dinajpur & & 2.014 & 1.277 & 0.509 & $7.381^{* * *}$ & 1.849 & 2.185 & 1.274 \\
\hline Thakurgoan & $3.903^{* *}$ & & $2.375^{*}$ & 0.221 & $11.011^{* * *}$ & $7.704^{* * *}$ & $4.908^{* * *}$ & 0.611 \\
\hline Panchagorh & $7.255^{* * *}$ & $15.917^{* * *}$ & & $2.422^{*}$ & $9.365^{* * *}$ & $12.162^{* * *}$ & $13.388^{* * *}$ & $2.978^{*}$ \\
\hline Gaibandha & $15.031^{* * *}$ & $15.37^{* * *}$ & $6.896^{* * *}$ & & $10.157^{* * *}$ & $21.136^{* * *}$ & $13.258^{* * *}$ & $6.343^{* * *}$ \\
\hline Rangpur & $6.11^{* * *}$ & $3.913^{* *}$ & 2.288 & 1.159 & & $4.548^{* *}$ & 2.289 & 2.128 \\
\hline Kurigram & $8.745^{* * *}$ & $3.192^{* *}$ & 0.82 & 0.108 & $7.448^{* * *}$ & & 1.785 & $3.045^{* *}$ \\
\hline Nilphamari & $4.55^{* *}$ & $9.054^{* * *}$ & 2.101 & 0.459 & $11.941^{* * *}$ & $8.74^{* * *}$ & & 1.909 \\
\hline Lalmonirhat & $6.266^{* * *}$ & $5.981^{* * *}$ & $4.174 * *$ & 1.504 & $10.984^{* * *}$ & $14.103^{* * *}$ & $4.721^{* * *}$ & \\
\hline
\end{tabular}

Note: The figures indicate the calculated $\mathrm{F}$ values associated with the hypothesis that there is no Granger causality from market $\mathrm{R}$ to $\mathrm{P}$ and vice versa.

* Significance at the $10 \%$ level

** Significance at the $5 \%$ level

*** Significance at the $1 \%$ level.

Source: Weekly wheat price series from 05/01/2006 to 31/12/2009 collected from DAM.

\subsection{Dynamic analysis of wheat market integration}

It is not sufficient to know that markets are integrated. It is also important to know the extent to which markets are integrated. This requires distinguishing between the short and long run impact of price changes emanating from one region to another. The speed of adjustment, as well as the length of time needed for prices to be transmitted from one market to another can be studied by dynamic adjustments.

The short run dynamics among the variables can be evaluated by examining the significance of the signs on the estimated lagged coefficients which are presented in Table 4. The short run results from the VECM revealed that all the estimated short run coefficients except for twenty three were statistically significant at a 5 percent and 10 
percent level of significance. The coefficient's values range between 0.002 and 0.51 . This suggests that the transmission of price changes from one market to another during the same week is moderate. The speed of the adjustment is given by the size of the adjustment coefficients. In co-integration equation 1, the price change in Panchagorh during the studied period was transmitted to the other markets at a rate of $21 \%$ within one week. On the other hand, adjustments towards the long run are extremely slower in the case of price changes in Dinajpur (10\%) Gaibandha (6\%) Kurigram (9\%), Lalmonirhat (3\%), Nilphamari (10\%), Rangpur (2\%) and Thakurgoan (2\%). In the case of equation 2, Lalmonirhat (39\%) showed faster transmission, while Gaibandha (7\%) showed slow transmission. In equation 3, Kurigram showed faster transmission and Thakurgoan showed slower transmission. Panchagorh and Rangpur showed faster and slower price transmission respectively in the case of equation 4. In equation 5, Nilphamari and Gaibandha indicated faster and slower movement of prices respectively. 


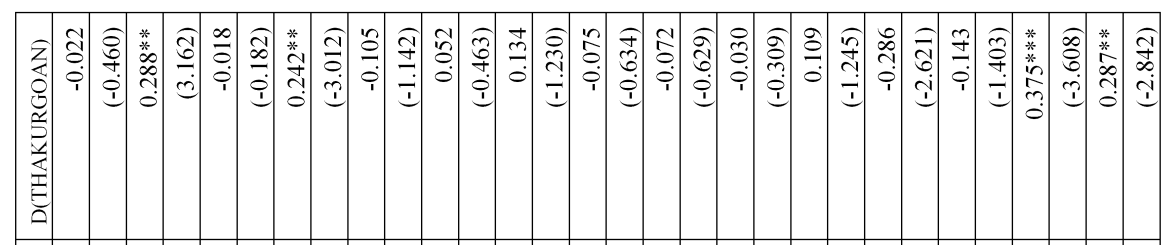

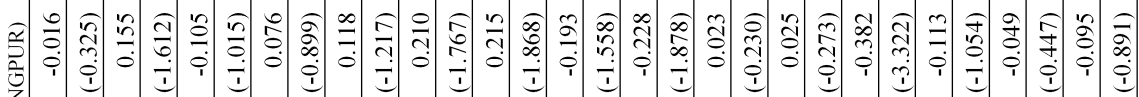
言

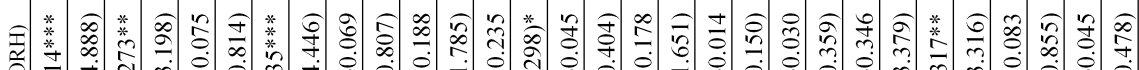

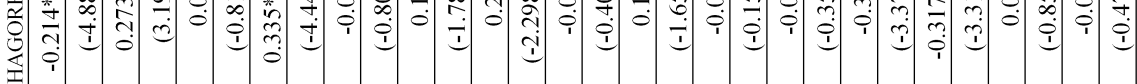

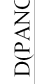

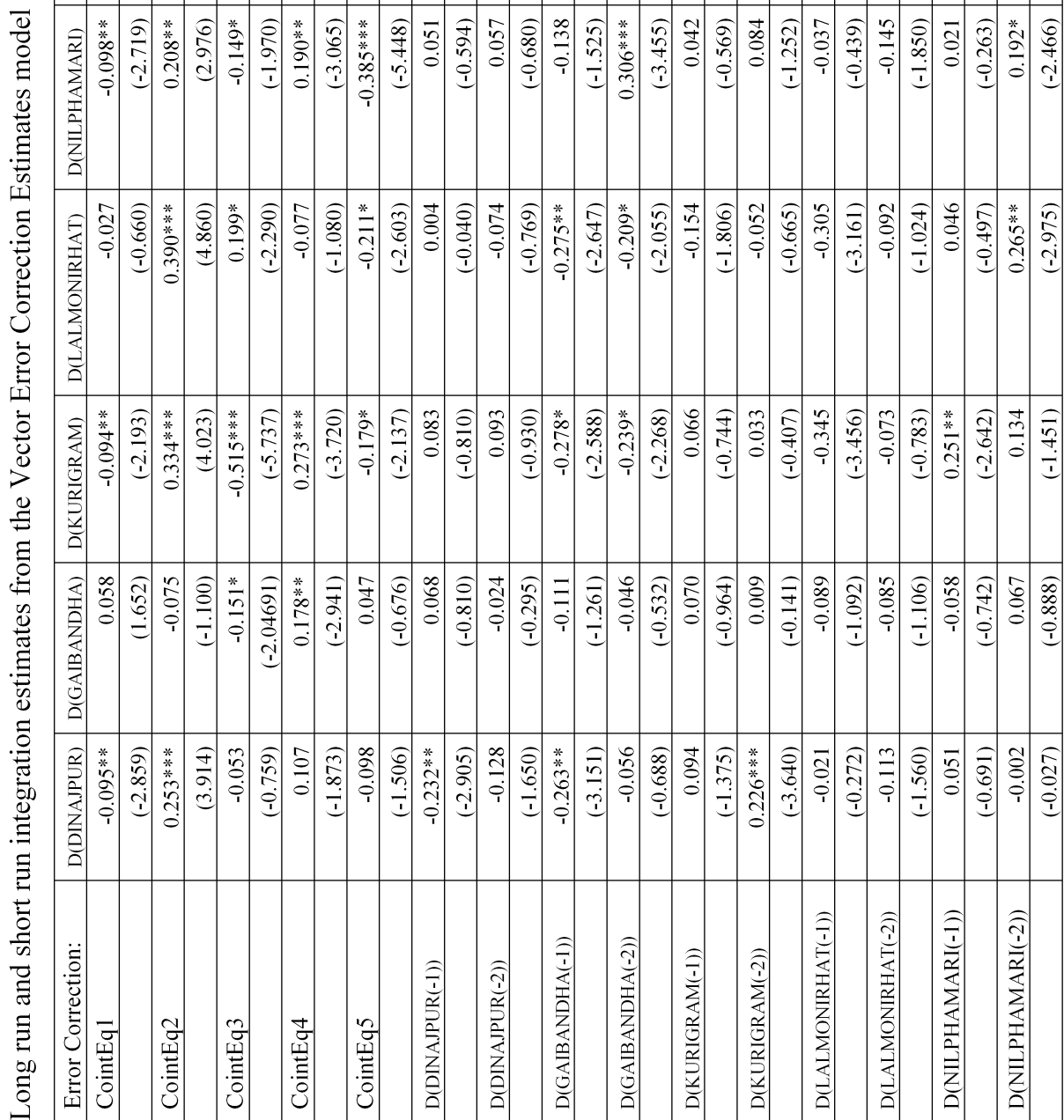




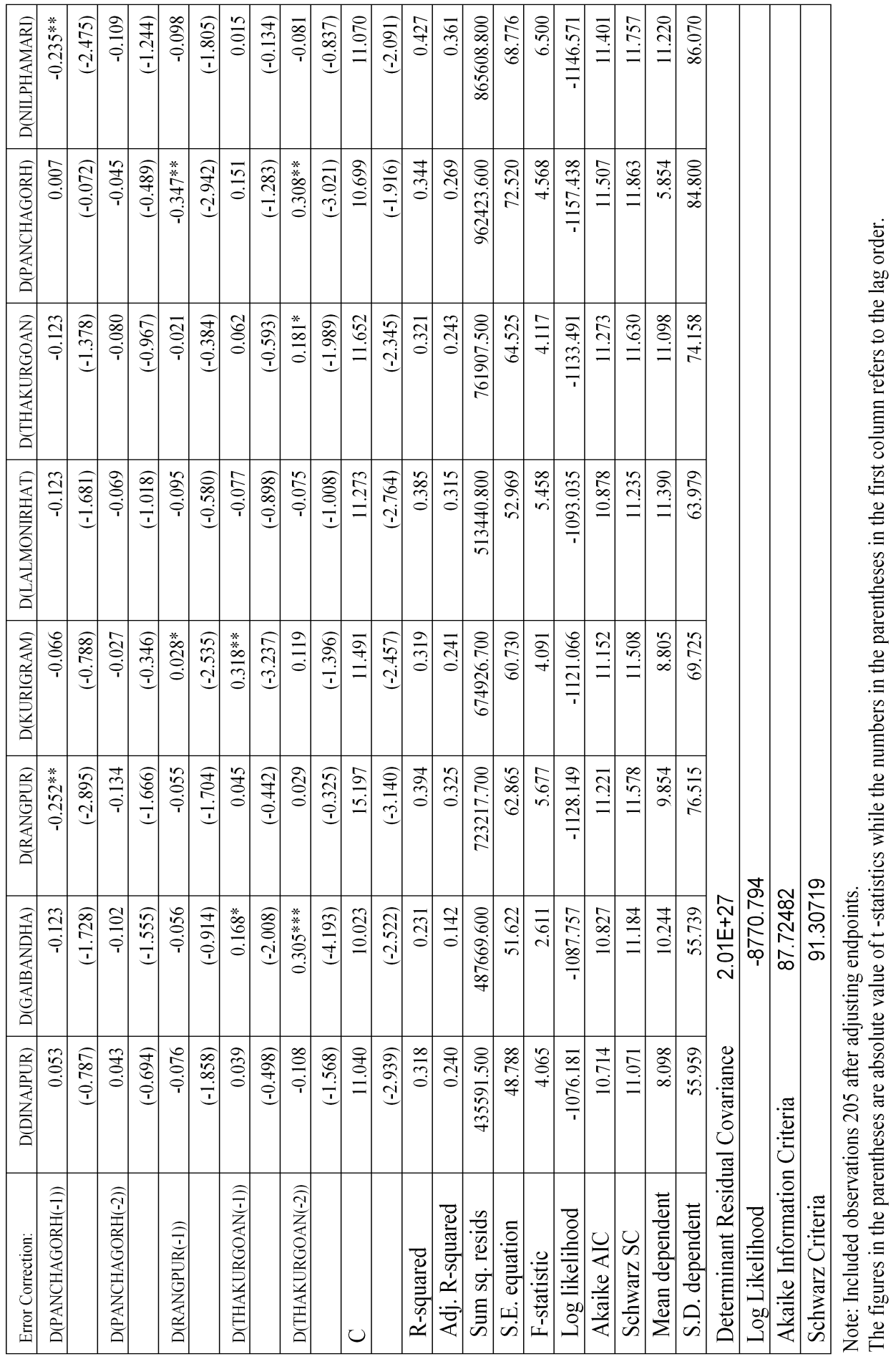




\section{Conclusion}

Due to the poor infrastructural and institutional facilities, agricultural commodity markets in developing countries are commonly less integrated. The coitegration test developed by Johansen and Jeselius (1990) has been used to check for Wheat market integration. This study utilized the Maximum likelihood (ML) method of cointegration. On the basis of this result, it has been concluded that the wheat markets in northern Bangladesh are integrated. The results show that there exists a long-run linear relationship between the prices in eight selected wheat markets in the Rangpur Division of Bangladesh. The special pricing relationships are consistent with market integration and suggest that the prices provide relevant signals to the selected wheat markets in Northern Bangladesh. VECM analyses results show that most of the markets showed slow price singles to each other.

These results have important policy implications. In a situation when the wheat markets are spatially integrated the government may think of reducing or even withdrawing its efforts to influence the price in the market. This finding regarding market integration appears to be quite significant for the success of price policy and market liberalization programs undertaken in Bangladesh. 


\section{References}

Alexander, C. and Wyeth, J. (1994). Cointegration and Market Integration: An Application to the Indonesian Rice Market, Journal of Development Studies, Vol. 30, No.2, pp. 303-32.

Asche, F., Bremnes, H. and Wessells, C.R. (1999). Product Aggregation, Market Integration, and Relationships between Prices: An Application to World Salmon Markets, American Journal of Agricultural Economics, Vol. 81, No.3, August, pp. 568-581.

Baharumshah, A.Z. and Habibbullah, S. (1994). Price Efficiency in Pepper Markets in Malaysia: A Cointegration Analysis, Indian Journal of Agricultural Economics, Vol. 49, No.2, April-June, pp. 205-215.

Barrett, C.B. (1996). Market Analysis Methods: Are our Enriched Toolkits Well Suited to Enlivened Markets? American Journal of Agricultural Economics. Vol. 78, No. 3, pp. 825-829.

Behura, Debdutt and Pradhan, D.C. (1998). Cointegration and Marke tIntegration: An Application to the Marine Fish Markets in Orissa, Indian Journal of Agricultural Economics, Vo. 53, July-September, pp.344-350.

Blyn, G. (1973). Price Series Correlation as a Measure of Market Integration, Indian Journal of Agricultural Economics, Vol. 28, No.2, April -June.

Chang, H.S. and Griffith, G. (1998). Examining Long-run Relationships between Australia Beef Prices, Australia Journal of Agricultural and Resource Economics. Vol. 42, No. 4, pp. 369-387.

Cummings, R. W., Jr. (1967). Pricing Efficiency in the Indian Wheat Market, New Delhi: Impex India.

Dahlgram, R.A. and Blank, S.C. (1992). Evaluating the Integration of Continuous Discontinuous Markets, American Journal of Agricultural Economics, Vol. 74, No.2, May, pp. 469-479.

Das, J. Zohir, S. and Baulch, B. (1997). The Spatial Integration and Pricing efficiency of the private Sector Grain Trade in Bangladesh. Report Prepared for DFID under RNRSS Crop Post-harvest Programme jointly by BIDS, Dhaka, Bangladesh and IDS, University of Sussex, Brighton, UK. 
Dercon, S. (1995). On Market Integration and Liberalisation: Method and. Application to Ethiopia, Journal of Development Studies, Vol. 32, No.1, pp. 112-143.

Dickey, D.A. and Fuller, W.A. (1981). Likelihood Ratio Statistics for Autoregressive Time Series with a Unit Root. Econometrica, Vol. 49, pp. 1057-72.

Engle, R.F. and Granger, C.W.J. (1987). Cointegration and Error Correction: Representation, Estimation and Testing, Econometrica, Vol. 50, pp.987-1007.

Faminow, M.D. and Benson, B.L. (1990). Integration of Spatial Markets, American Journal of Agricultural Economics, Vol. 72, No.1, February, pp. 49-62.

Ghosh, M. (2000). Cointegration Tests and Spatial Integration of Rice Markets in India, Indian Journal of Agricultural Economics, Vol. 55, No.4, OctoberDecember, pp.616-625.

Gilbert, E.H. (1969). Marketing of Staple Foods in Northern Nigeria: A Study of Staple Food Marketing Systems Serving Kano City, Ph. D. Dissertation, Stanford University, Stanford, California.

Goletti, F., Ahmed, R. and Fraid, N. (1995). Structural Determinants of Market Integration: The Case of Rice Markets in Bangladesh, The Developing Economics, Vol. 33, No.2, pp. 185-202.

Goodwin, B.K. and Schroeder, T.C. (1991). Cointegration Tests and Spatial Price Linkages in Regional Cattle Markets, American Journal of Agricultural Economics, Vol. 73, No.2, May, pp.452-464.

Gupta, R.P. (1973). Agricultural Prices in a Backward Economy, Delhi, National.

Harriss, B. (1979). There is Method in My Madness: Or Is It Vice Versa? Measuring Agricultural Market Performance, Food Research Institute Studies, Vol. 17, No.2.

Heytens, P.J. (1986). Testing Market Integration, Food Research Institute Studies, Vol. XX, No.1, pp. 25-41.

Hossain, M.I. and Verbeke, W. (2008). Farmers and Private Traders Response to Rice Markets Liberalization in Bangladesh, Journal of International Logistics and Trade, Vol. 6, No. 1, pp. 1-21.

Hossain, M.I. and Verbeke, W. (2010). Evaluation of Rice Markets Integration in Bangladesh. Lahore Journal of Economics, Vol.15, No.2, pp.77-96. 
Illori, A. (1968). Economic Study of Production and Distribution of Staple Food Crops in Western Nigeria, Ph. D. Dissertation, Stanford University, Stanford, California.

Ismet, Barkley and Llewen (1998). Government Intervention and Market Integration in Indonesian Rice Markets, Agricultural Economics. Vol. 19, pp. 283-95.

Johansen, S.K. (1988). Statistical Analysis of Cointegration Vectors, Journal of Economic Dynamics and Control. Vol. 12, pp. 231-54.

Johansen, S.K. (1991). Estimation and Hypothesis Testing of Cointegration Vectors in the Presence of Linear Trend, Economerica. Vol. 59, pp. 151-58.

Johansen, S.K. and Juselius, K. (1990). Maximum Likelihood Estimation and Inference on Cointegration with Application to the Demand for Money, Oxford Bulletin of Economics and Statistics. Vol. 52, pp. 169-210.

Jones, W.O. (1972). Marketing Staple Food Crops in Tropical Africa, Cornell University Press. Ithaca, NY.

Lele, U.J. (1967). Market Integration: A Study of Sorghum Prices in Western India, Journal of Farm Economics, Vol. 49, pp. 14-59.

Lele, U.J. (1971). Food Grain Marketing in India, Private Performance and Public Policy, Ithaca, NY: Cornell University Press.

Minten, B. (1999). Infrastructure, Market Access, and Agricultural Prices: Evidence from Madagascar. IFPRI Discussion Paper No.26. Washington D.C.

Palaskas, T .B. and Harriss- White, B. (1993). Testing Market Integration: New Approaches with Case Material from the West Bengal, Food Economy, The Journal of Development Studies, Vol. No.1, October, pp. 1-57.

Perron, P. (1988). rends and Random Walks in Macroeconomic Time Series, Journal of Economic Dynamics and Control. Vol. 12, pp. 297-332.

Ravallion, M. (1983). A Method with Less Madness: Modelling Market Integration in Agriculture, Queen Elizabeth House, Oxford University, mimeograph.

Ravallion, M. (1986). Testing Market Integration, American Journal of Agricultural Economics, Vol. 68, No.1, pp. 102-9.

Sexton, R., Kling, C. and Carmar, H. (1991). Market Integration, Efficiency of Arbitrage and Imperfect Competition: Methodology and an Application to U.S.Celery, American Journal of Agricultural Economics, 7, May, pp. 568-80. 
Thakur, D.S. (1974). Food Grain Marketing Efficiency: A Case Study of Gujarat, Indian Journal of Agricultural Economics, Vol. 29, No.4, October - December, pp. 61-65. 
